\title{
Laparoscopic nerve-sparing radical trachelectomy: retrospective study of four patients
}

\author{
Laparoskopowa radykalna trachelektomia oszczędzająca nerwy: \\ retrospektywna analiza czterech pacjentek
}

Department of Surgical and Gynaecological Oncology, Galaxy Care Laparoscopy Institute, Opposite Garware College, 25-A, Ayurvedic Rasashala Premises, Karve Road, Pune, Maharashtra - 411004, India Correspondence: Dr. Shailesh Puntambekar, Department of Surgical and Gynaecological Oncology, Galaxy Care Laparoscopy Institute, Opposite Garware College, 25-A, Ayurvedic Rasashala Premises, Karve Road, Pune, Maharashtra - 411004, India, tel.: +91-9822023706, e-mail: shase63@gmail.com

\begin{abstract}
Introduction: Cervical cancer is the third most common cancer in females worldwide. The standard proposed treatment for early-stage carcinoma cervix (IA1-IB1) is radical hysterectomy. Patients desirous of fertility can undergo laparoscopic radical trachelectomy. The aim of this study is to present a series of 4 patients with early-stage cervical cancer who underwent total laparoscopic nerve-sparing radical trachelectomy and laparoscopic pelvic lymphadenectomy. We describe our surgical technique, and compare our results for surgical, oncological and reproductive outcomes with other available studies. Materials and methods: A retrospective review study of 4 patients with early-stage cervical cancer who underwent total laparoscopic nerve-sparing radical trachelectomy and laparoscopic pelvic lymphadenectomy in the Galaxy Care Laparoscopy Institute, India between 2016 and 2018. Results: Four cases of laparoscopic nerve-sparing radical trachelectomy performed in young patients with stages ranging from IA2 to IB1 invasive squamous cell carcinoma of the cervix. The operative time was 100-150 minutes. The intraoperative and postoperative periods were uneventful. The histopathology report was confirmatory with free margins, and pelvic lymph nodes did not show any tumor metastasis. At routine follow-up, all patients started menstruating, and the bowel-bladder function was normal. All patients had satisfying sexual history in the postoperative period, without any complaints of vaginal dryness or difficulty in coitus. A total of 3 patients attempted conceiving, and 2 succeeded. No recurrence has been seen to date. Conclusion: Laparoscopic nerve-sparing trachelectomy in young females desiring fertility is a preferred technique in early-stage cervical cancer. Nerve-sparing techniques specifically enable the prevention of urinary dysfunction, and anorectal and sexual problems postoperatively.
\end{abstract}

Keywords: laparoscopic, nerve-sparing, trachelectomy, cervical cancer

Wstęp: Rak szyjki macicy jest trzecim pod względem częstości zachorowań nowotworem u kobiet na świecie. Standardowo stosowaną metodą leczenia tego nowotworu we wczesnym stadium (IA1-IB1) jest radykalna histerektomia. U pacjentek, które chcą zachować płodność, można stosować laparoskopową radykalną trachelektomię. Celem pracy jest przedstawienie serii czterech pacjentek z rakiem szyjki macicy we wczesnym stadium, u których wykonano laparoskopową radykalną trachelektomię oszczędzającą nerwy oraz laparoskopową limfadenektomię miednicy. W pracy opisujemy stosowaną przez nas technikę operacyjną i porównujemy uzyskane wyniki chirurgiczne, onkologiczne i reprodukcyjne z badaniami dostępnymi w literaturze. Materiały i metody: Przeprowadzono retrospektywne badanie przeglądowe obejmujące cztery pacjentki z rakiem szyjki macicy we wczesnym stadium, u których w latach 2016-2018 w Galaxy Care Laparoscopy Institute (Indie) wykonano laparoskopową radykalną trachelektomię oszczędzającą nerwy i laparoskopową limfadenektomię miednicy. Wyniki: Cztery przypadki laparoskopowej radykalnej trachelektomii oszczędzającej nerwy u młodych pacjentek z inwazyjnym rakiem płaskonabłonkowym szyjki macicy w stadium od IA2 do IB1. Czas zabiegu wyniósł 100-150 minut. Okres śród- oraz pooperacyjny przebiegł bez powikłań. W badaniu histopatologicznym potwierdzono rozpoznanie wraz z marginesami wolnymi. Nie odnotowano zmian przerzutowych do węzłów chłonnych miednicy. Przy rutynowej kontroli stwierdzono, że u wszystkich pacjentek wystąpiła menstruacja; nie zgłaszano upośledzenia czynności jelit ani pęcherza moczowego. Wywiad dotyczący życia seksualnego pacjentek w okresie pooperacyjnym nie wykazał dolegliwości związanych z suchością pochwy ani trudności w odbyciu stosunku seksualnego. Trzy pacjentki podjęły próbę zajścia w ciążę, z czego u dwóch kobiet próba ta zakończyła się powodzeniem. Do czasu opracowania publikacji u żadnej pacjentki nie odnotowano nawrotu choroby. Wnioski: Laparoskopowa trachelektomia 
oszczędzająca nerwy jest preferowaną metodą chirurgiczną u młodych pacjentek z rakiem szyjki macicy we wczesnym stadium, które chcą zachować płodność. Techniki chirurgiczne oszczędzające nerwy zapobiegają pooperacyjnemu upośledzeniu czynności układu moczowego, nieprawidłowościom odbytniczo-odbytowym i problemom w sferze seksualnej.

Słowa kluczowe: laparoskopowa, oszczędzająca nerwy, trachelektomia, rak szyjki macicy

\section{INTRODUCTION}

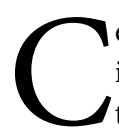
ervical cancer is the third most common cancer in females worldwide, and approximately $85 \%$ of these cases and deaths occur in developing countries $^{(1)}$. The standard proposed treatment for early-stage carcinoma cervix (IA1-IB1) was radical hysterectomy ${ }^{(2)}$. Dargent et al. in 1994 first described vaginal radical trachelectomy $(\mathrm{VRT})^{(3)}$, whereas open abdominal radical trachelectomy (ART) was introduced by Smith et al. later ${ }^{(4)}$. Both VRT and ART were fertility-sparing trachelectomy techniques which changed the overall approach for early cervical cancer surgeries.

Patients desirous of fertility can undergo radical trachelectomy either by abdominal, vaginal or laparoscopic route ${ }^{(2)}$. Laparoscopic radical trachelectomy (LRT) is now emerging as the new mode of management in minimal invasive cancer surgery. The aim of this study is to present a series of 4 patients with early-stage cervical cancer who underwent total laparoscopic nerve-sparing radical trachelectomy (TLNSRT) and laparoscopic pelvic lymph node dissection (LPLND) at our institute. We describe our surgical technique of TLNSRT, and compare our results for surgical, oncological and reproductive outcomes with other available studies.

\section{MATERIALS AND METHODS}

A retrospective review study of 4 patients with early-stage cervical cancer who underwent TLNSRT and LPLND was carried out in the Galaxy Care Laparoscopy Institute, Pune, Maharashtra, India between $1^{\text {st }}$ January 2016 and $31^{\text {st }}$ December 2018. All 4 surgeries were performed by same surgical team headed by Dr. Shailesh Puntambekar.

The demographic details of all patients were recorded as per protocol. All patients underwent necessary investigations

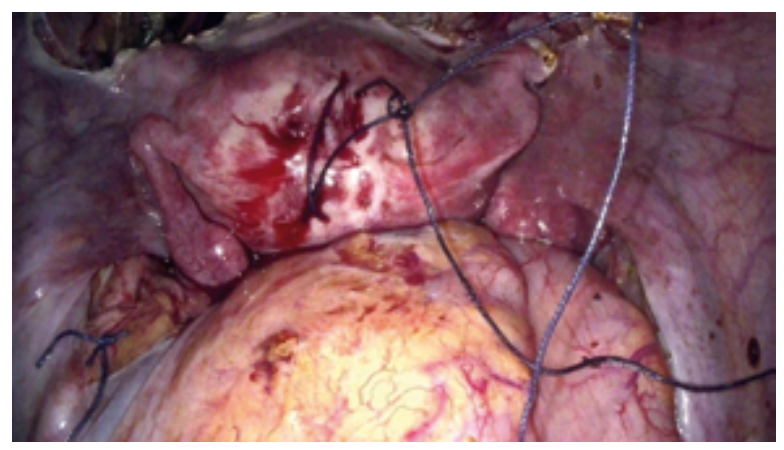

for confirmation of diagnosis of cervical cancer including PAP smear, colposcopy and biopsy, and magnetic resonance imaging (MRI) of the pelvis.

The inclusion criteria were: (1) patient desirous of fertility, (2) tumor size less than $2 \mathrm{~cm}$ in the largest diameter, (3) International Federation of Gynecology and Obstetrics (FIGO) stages IA1 to IB1, (4) absence of distant metastasis on MRI, (5) absence of unfavorable histologic types (smallcell carcinoma, neuroendocrine tumors, sarcoma), (6) no suspicion of pelvic lymph node involvement and no deep stromal invasion $(>10 \mathrm{~mm})$. Patients not meeting the above criteria were excluded from the study.

All patients were informed about their malignancy, and all the available modalities of treatment were explained in detail to them including the chances of future pregnancy. Informed and written consent were obtained from all patients prior to surgery.

\section{Surgical technique of TLNSRT}

The patient was placed in the modified Lloyd-Davies position at 30-45 degree tilt. A total of 5 ports were used: a $10 \mathrm{~mm}$ camera port at the umbilicus and a $10 \mathrm{~mm}$ working port at the right McBurney's point, a $5 \mathrm{~mm}$ port in the para-rectus position in the mid-clavicular line. Mirror image ports were placed on the left side. The surgeon operated from the right side, and the assistant was on the left side. The uterus was hitched at the level of fundus to the anterior abdominal wall using Vicryl No. 1 sutures (Fig. 1).

The dissection started with cutting the round ligament on the right side with the help of harmonic shears and extending the cut downwards towards the utero-vesical fold. Traction was given to the uterus by the assistant surgeon by pulling the uterus cranially holding the opposite ovarian ligament. The bladder was pushed down after dissecting

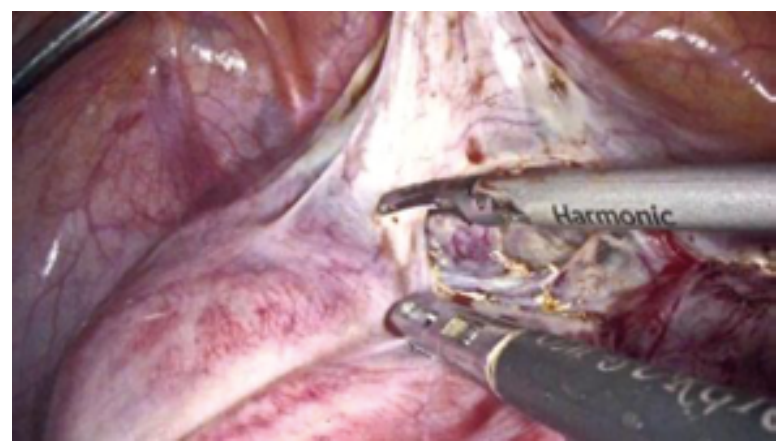

Fig. 2. Dissecting the uterovesical fold starting from the rightsided round ligament 


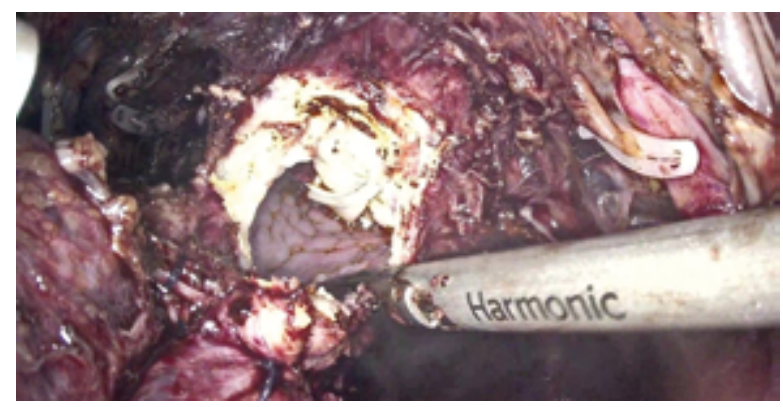

Fig. 3. Colpotomy after stitching the vagina below the level of the external os

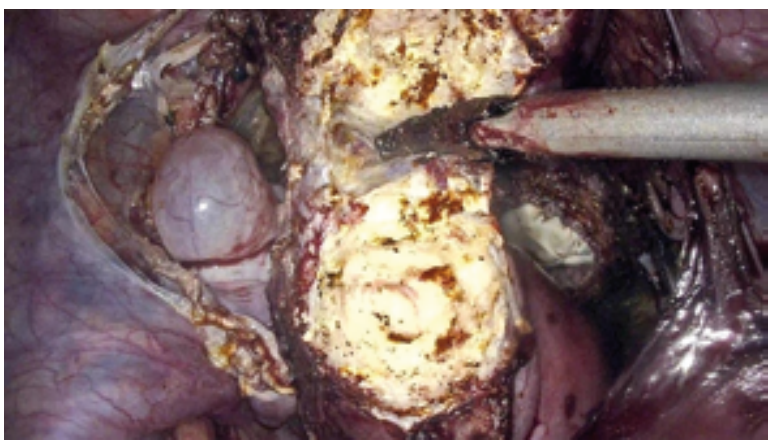

Fig. 4. Proximal part of the cervix cut with the help of harmonic shears

the uterovesical fold. The dissection was carried out until the opposite round ligament was reached (Fig. 2).

A posterior ' $U$ ' cut was started from the right side. The peritoneum medial to the infundibulopelvic ligament (IP ligament) was lifted, and the ureter was visualized at the level of the sacral promontory. The fold of the peritoneum was cut medial to the ureter (Okabayashi's space), and dissection was carried out until reaching the pouch of Douglas (POD), keeping the ureter laterally. The inferior hypogastric nerve and its branches to the rectum, cervix and urinary bladder were dissected in this space and preserved. A similar procedure was done on the opposite side using harmonic shears. With cranial traction to the rectum, the peritoneum was opened in the $\mathrm{POD}$, and the posterior vaginal wall was further dissected from the rectum.

The left ureter was then retracted medially, and the dissection was carried out parallel and lateral to the ureter to open the lateral pararectal space (Latzko's space) with the help of harmonic shears. The internal iliac artery forms the lateral boundary of this space. Further dissection along the ureter anteriorly identified the uterine artery, as it is the only structure which crosses this space from lateral to medial. The uterine artery was traced to its origin from the anterior division of the internal iliac artery and cauterized, clipped and cut. The uterine vein passing from below the ureter was also cauterized, clipped and cut medial to the inferior hypogastric nerve and its branches. The uterosacral and cardinal ligaments were cut with harmonics preserving the hypogastric nerves supplying the bladder and uterus.

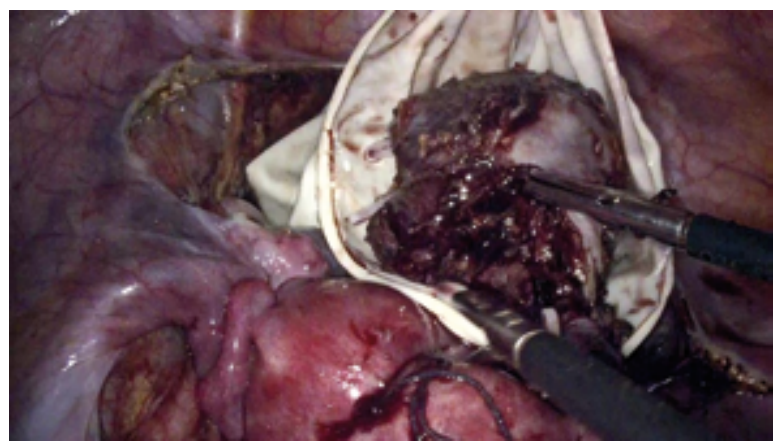

Fig. 5. Specimen inserted into the endo-bag and exteriorized through the vault

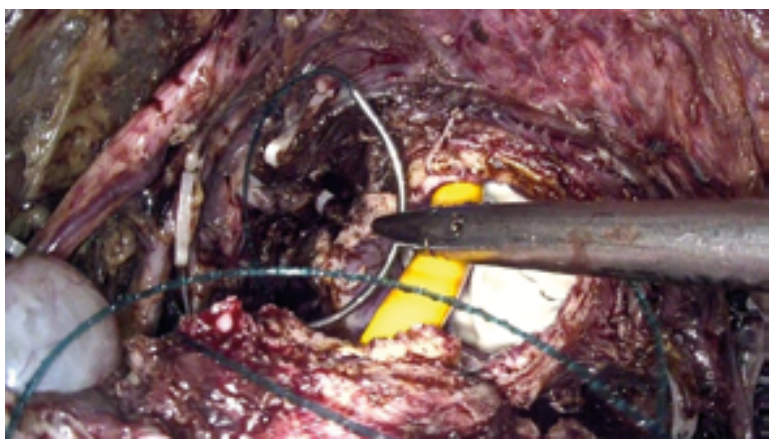

Fig. 6. Isthmus of the uterus sutured with the vaginal vault

Ureteric tunnel dissection was done with the aid of Maryland forceps which helped to visualize the ureter as far as the uretrovesical junction. Similar steps were repeated on the right side, and the bladder was pushed further down. A purse string suture with Vicryl No. 1 was taken below the level of the external os to prevent the spillage of contents in the abdominal cavity as well as in the vagina while exteriorizing the specimen. A cut was made posteriorly at the origin of the uterosacral ligament, and colpotomy was done. The incision extended circumferentially, and the uterus with the cervix was separated from vagina with the help of harmonic shears (Figs. 3, 4).

The peritoneum was cut at the bifurcation of the left common iliac artery, and the dissection was carried out medial to the external iliac vessels with the help of suction cannula. All the fibrofatty tissue present along the external iliac vessels medially was removed until the obturator nerve and iliac bone were reached. A similar procedure was done on the right side (Figs. 5, 6).

A thorough normal saline wash was given, and the bladder and rectum were checked for any serosal or mucosal tears. After confirmation of no bladder and rectum injury, the isthmus of the uterus was sutured with the vaginal vault using barbed sutures in a continuous manner with no 14 Foley catheter inside the endometrial cavity. The round ligament cut ends were re-sutured, and the anterior uterovesical fold of the peritoneum was closed. Cervical cerclage was not done, as it might cause irritation of the anastomotic site. No intraoperative complications were seen (Fig. 7). 


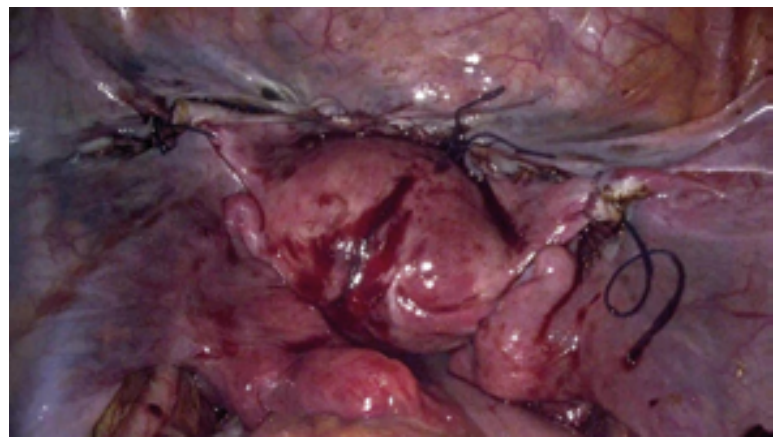

Fig. 7. Bilateral round ligaments and uterovesical folds closed back
The surgical approach for laparoscopic pelvic lymphadenectomy (LPL) was as per standard treatment for any cervical cancer, and the nerve-sparing intent did not require any specific different techniques.

The total operative time and blood loss were noted after each surgery. The Foley catheter was removed from the uterus on postoperative day 1, and the urinary Foley catheter was removed on postoperative day 2 in view of the nerve-sparing surgery. The patients were asked to maintain abstinence from sexual activity for 4 weeks.

The patients were followed up on postoperative day 7 , and the post-void residual urine and bowel functions were

\begin{tabular}{|c|c|c|c|c|}
\hline Parameter & Case 1 & Case 2 & Case 3 & Case 4 \\
\hline Age [years] & 24 & 32 & 29 & 31 \\
\hline Gravidity, parity, abortion history & $\mathrm{G} 2 \mathrm{POA} 2$ & G1P1A0 & GOPOAO & $\mathrm{G} 2 \mathrm{P} 2 \mathrm{AO}$ \\
\hline $\begin{array}{l}\text { PAP smear and human } \\
\text { papilloma virus (HPV testing, if } \\
\text { done - high-risk type - } 16,18 \text {, } \\
31,33,34,35,39,45,51,52 \text {, } \\
56,58,59)\end{array}$ & $\begin{array}{l}\text { Atypical squamous cells. } \\
16 \text { and } 51 \text { positive }\end{array}$ & $\begin{array}{l}\text { Atypical squamous cells. } \\
16,18,35 \text { positive }\end{array}$ & $\begin{array}{l}\text { Atypical squamous cells. } \\
33,34,35,39 \text { positive }\end{array}$ & $\begin{array}{l}\text { Atypical squamous cells. } \\
\text { HPV testing not done }\end{array}$ \\
\hline Colposcopic biopsy & Squamous cell carcinoma (SCC) & $\mathrm{SCC}$ & $\mathrm{SCC}$ & $\mathrm{SCC}$ \\
\hline Per vaginal examination & \begin{tabular}{|c|} 
Cervix: no gross lesion. \\
Parametrium and upper vagina: \\
free from tumor
\end{tabular} & $\begin{array}{c}\text { Cervix: thickened wall. } \\
\text { Parametrium and upper vagina: } \\
\text { free from tumor }\end{array}$ & \begin{tabular}{|c|} 
Cervix: palpable lesion? \\
Parametrium and upper vagina: \\
free from tumor
\end{tabular} & $\begin{array}{c}\text { Cervix: no gross lesion. } \\
\text { Parametrium and upper vagina: } \\
\text { free from tumor }\end{array}$ \\
\hline MRI & $\begin{array}{l}\text { Thickening of anterior lip } \\
\text { of cervix with no adjacent } \\
\text { structure involvement }\end{array}$ & $\begin{array}{c}\text { Thickening of anterior and } \\
\text { posterior lip of cervix with no } \\
\text { adjacent structure involvement }\end{array}$ & $\begin{array}{c}\text { Visible growth of } 1.7 \times 1.1 \mathrm{~cm} \\
\text { on anterior cervical wall without } \\
\text { any deep infiltration or adjacent } \\
\text { structure involvement }\end{array}$ & $\begin{array}{c}\text { Diffuse thickening of anterior lip } \\
\text { of cervix without any obvious } \\
\text { visualized growth or lesion }\end{array}$ \\
\hline FIGO staging & $\mathrm{IA} 2$ & 1B1 & 1B1 & $1 \mathrm{~A} 2$ \\
\hline Histopathological report (HPR) & \begin{tabular}{|c|} 
SCC. Margins: free of tumor. \\
Residual tumor: nil. Pelvic lymph \\
nodes: no metastasis \\
\end{tabular} & \begin{tabular}{|c|} 
SCC. Margins: free of tumor. \\
Residual tumor: nil. Pelvic lymph \\
nodes: no metastasis \\
\end{tabular} & \begin{tabular}{|c|} 
SCC. Margins: free of tumor. \\
Residual tumor: nil. Pelvic lymph \\
nodes: no metastasis \\
\end{tabular} & \begin{tabular}{|c|} 
SCC. Margins: free of tumor. \\
Residual tumor: nil. Pelvic lymph \\
nodes: no metastasis \\
\end{tabular} \\
\hline $\begin{array}{l}\text { Mean numbers of pelvic lymph } \\
\text { nodal yield }\end{array}$ & 24 & 22 & 31 & 19 \\
\hline $\begin{array}{l}\text { Average intraoperative blood } \\
\text { loss }[\mathrm{mL}]\end{array}$ & 70 & 90 & 100 & 60 \\
\hline Operative time [minutes] & 120 & 110 & 160 & 90 \\
\hline $\begin{array}{l}\text { Postoperative hospital stay } \\
\text { [days] }\end{array}$ & 3 & 4 & 6 & 3 \\
\hline $\begin{array}{l}\text { Duration of postoperative } \\
\text { catheterization [DPC in days] }\end{array}$ & 2 & 2 & 2 & 2 \\
\hline $\begin{array}{l}\text { Post-void residual volume } \\
\text { on day } 7[\mathrm{~mL}]\end{array}$ & 10 & 15 & 25 & 20 \\
\hline Urinary complaints & \begin{tabular}{|c|} 
Incontinence: none. \\
Retention: none. Dysuria: none. \\
Urgency: none
\end{tabular} & $\begin{array}{c}\text { Incontinence: none. } \\
\text { Retention: none. Dysuria: none. } \\
\text { Urgency: none } \\
\end{array}$ & \begin{tabular}{|c|} 
Incontinence: none. \\
Retention: none. Dysuria: none. \\
Urgency: none
\end{tabular} & $\begin{array}{c}\text { Incontinence: none. } \\
\text { Retention: none. Dysuria: none. } \\
\text { Urgency: none } \\
\end{array}$ \\
\hline Anorectal complaints & $\begin{array}{l}\text { Constipation: none. Diarrhea: } \\
\text { none. Fecal incontinence: none }\end{array}$ & $\begin{array}{l}\text { Constipation: none. Diarrhea: } \\
\text { none. Fecal incontinence: none }\end{array}$ & $\begin{array}{l}\text { Constipation: none. Diarrhea: } \\
\text { none. Fecal incontinence: none }\end{array}$ & $\begin{array}{l}\text { Constipation: none. Diarrhea: } \\
\text { none. Fecal incontinence: none }\end{array}$ \\
\hline $\begin{array}{l}\text { Vaginal dryness and difficulty } \\
\text { in coitus }\end{array}$ & None & None & None & None \\
\hline Dyspareunia & None & None & None & None \\
\hline $\begin{array}{l}\text { Sexual satisfaction } \\
\text { (NONE, POOR, AVERAGE, GO0D) } \\
\end{array}$ & GOOD & GOOD & AVERAGE & GOOD \\
\hline $\begin{array}{l}\text { Menstrual cycle after surgery } \\
\text { [month] }\end{array}$ & $1^{\text {st }}$ & $1^{\text {st }}$ & $2^{\text {nd }}$ & $1^{\text {st }}$ \\
\hline $\begin{array}{l}\text { Pregnancies post operation } \\
\text { to date }\end{array}$ & 1 & Nil (not conceived) & 1 & None \\
\hline Recurrence for 2 years & None & None & None & None \\
\hline
\end{tabular}




\begin{tabular}{|c|c|c|c|c|c|c|c|}
\hline $\begin{array}{l}\text { Parameters } \\
\text { of comparison }\end{array}$ & $\begin{array}{l}\text { Lee } \\
\text { et al. } .^{(12)}\end{array}$ & $\begin{array}{l}\text { Bafghi } \\
\text { et al. }{ }^{\left({ }^{10)}\right.}\end{array}$ & $\begin{array}{l}\text { Park } \\
\text { et al. }{ }^{(11)}\end{array}$ & $\begin{array}{l}\text { Rendón } \\
\text { et al. } .^{(2)}\end{array}$ & $\begin{array}{c}\text { Martin } \\
\text { and Torrent }{ }^{(9)}\end{array}$ & $\begin{array}{l}\text { Kim } \\
\text { et al. } .^{(13)}\end{array}$ & $\begin{array}{c}\text { Puntambekar } \\
\text { et al. }\end{array}$ \\
\hline Number of patients & 2 & 6 & 4 & 1 & 9 & 27 & 4 \\
\hline Mean age [years] & 32 & 30 & 29.5 & 31 & NA & 29 & 29 \\
\hline Stage of disease & $|B|-2$ & $\begin{array}{l}|A| \mid-2 \\
|B|-4 \\
\end{array}$ & $\begin{array}{l}|\mathrm{A}| \mathrm{I}-1 \\
|\mathrm{~B}|-3\end{array}$ & $|\mathrm{~B}|$ & $\begin{array}{l}\text { IAII-2 } \\
\text { IB1-7 } \\
\end{array}$ & $\begin{array}{l}\mid \mathrm{IBI}-26 \\
\mathrm{IIA}-1\end{array}$ & $\begin{array}{l}|A| \mid-2 \\
|B|-2 \\
\end{array}$ \\
\hline Histological type & SCC & $\begin{array}{c}\text { SCC }-5 \\
\text { 0ther - } 1\end{array}$ & $\mathrm{SCC}$ & Adenocarcinoma & $\begin{array}{c}\mathrm{SCC}-6 \\
\text { Adenocarcinoma }-3\end{array}$ & $\begin{array}{c}\mathrm{SCC}-20 \\
\text { Adenocarcinoma }-6 \\
\text { Others }-1 \\
\end{array}$ & $\mathrm{SCC}$ \\
\hline $\begin{array}{l}\text { Lymphovascular space } \\
\text { invasion (LVSI) }\end{array}$ & NA & 1 & NA & 0 & NA & 0 & 0 \\
\hline $\begin{array}{l}\text { Mean number of lymph } \\
\text { nodes }\end{array}$ & 35 & 18 & NA & 10 & NA & 25.7 & 24 \\
\hline Average blood loss [mL] & 650 & NA & 185 & 100 & NA & 332 & 80 \\
\hline $\begin{array}{l}\text { Mean operative time } \\
\text { [minutes] }\end{array}$ & 352.5 & 201 & 250 & 340 & 270 & 290 & 120 \\
\hline Transfusions & NA & $\mathrm{NA}$ & 0 & 0 & NA & 6 & None \\
\hline Mean hospital stay [days] & 12.5 & 4.5 & 6 & 2 & NA & 9 & 4 \\
\hline Miscarriages post surgery & NA & 1 & 0 & 0 & NA & 2 & 0 \\
\hline Pregnancies post surgery & NA & 2 & 0 & 0 & 2 & 3 & 2 \\
\hline Recurrence rate & 0 & 1 & 1 & 0 & 1 & 1 & 0 \\
\hline
\end{tabular}

Tab. 2. Available literature studies and their data for comparison

evaluated. All the patients were followed up at months 1, 3 and 6 , and years 1 and 2 . They were asked in detail about any complaints of urinary incontinence, urinary retention, dysuria, urgency, anorectal dysfunctions such as constipation, diarrhea, and fecal incontinence. Furthermore, detailed history of reduced libido, vaginal dryness, difficulty in coitus, dyspareunia, and a decrease in orgasm was reported. Sexual satisfaction was marked by patients themselves on a scale of NONE, POOR, AVERAGE, GOOD.

The histopathology reports of all patients with margin status, residual tumor and pelvic lymph node yield were noted carefully. Menstrual cycle details, pregnancy status and miscarriages, if any, with recurrence rates were meticulously noted. All data was compiled in a database using Microsoft Excel.

\section{RESULTS}

The detailed findings of all 4 patients are listed in Tab. 1.

\section{DISCUSSION}

Cervical cancer is one of the leading causes of cancer-related deaths in the female population worldwide ${ }^{(1)}$. Latest diagnostic modalities and better screening programs for cervical cancer have led to early detection of cancer mainly in young females. The treatment for early cervical cancer i.e. FIGO stages IA1 to IB2, is mainly radical surgery with or without subsequent radiotherapy, depending on presence or absence of adjunctive risk factors (lymphovascular invasion, grading).

Radical surgery often does not spare fertility, leading to psychosexual dysfunction and poor quality of life ${ }^{(5,6)}$. An increase in the number of younger patients with cervical cancer desirous of future pregnancy has recently led to a revision in the radical surgical approaches, so that fertility can be preserved without compromising the oncological principles.

There are ample studies advocating vaginal radical trachelectomy as well as open abdominal radical trachelectomy, but very few regarding laparoscopic fertility-preserving nerve-sparing radical trachelectomy. Cibula et al. in 2005 first reported the case of laparoscopic radical trachelectomy and considered it an alternative technique which can be practiced if one has an adequate knowledge of laparoscopic surgery $^{(7)}$. According to Rendón et al., only 44 cases of laparoscopic abdominal radical trachelectomy had been reported until 2012 in the available literature ${ }^{(2)}$, whereas Vieira et al. in 2015 in their retrospective study noted that there were only 42 patients who underwent minimally invasive surgery (laparoscopic or robotic) for early cancer cervix ${ }^{(8)}$. We had a total of 4 patients in our study, similarly to other studies in their series ${ }^{(2,9-12)}$. The largest series published to date is that by Kim et al., consisting of a total of 27 patients who underwent laparoscopic trachelectomy ${ }^{(13)}$. The mean patient age in our study was 29 years (range: $24-31$ ), and the result was consistent with other available studies (Tab. 2).

All the available literature studies like ours were strict with respect to the inclusion criteria, and hence all the patients had early-stage cervical cancer (FIGO IA1-IB1). All patients in our series were diagnosed with squamous cell carcinoma (SCC), whereas Martin and Torrent in their study of 9 patients had 3 patients with adenocarcinoma ${ }^{(9)}$. Lymphovascular space invasion was noted in 1 out of 10 patients in the study by Bafghi et al., necessitating referral for radiation and chemotherapy ${ }^{(10)}$, however, other studies like ours did not encounter this. 
There was a vast difference in operative time across different available literature studies. Our mean operative time was $120 \mathrm{~min}$, with a range of 90 to $160 \mathrm{~min}$. Bafghi et al. had a mean surgery time of $201 \mathrm{~min}^{(10)}$, and other studies had their mean operative times of $352.5 \mathrm{~min}, 340 \mathrm{~min}$, and 270 min, respectively ${ }^{(2,9,12)}$ (Tab. 2). Comparing to other available studies with ART or VRT, the duration of surgery was significantly longer in laparoscopy. Kucukmetin et al. mention that the median operative time was longer with the laparoscopic approach compared to the laparotomic approach (320 vs. 192.5 minutes) ${ }^{(14)}$. Vieira et al. observed that the median surgical time for minimal invasive surgery (MIS) including laparoscopic or robotic modalities was $272 \mathrm{~min}$ (range: 130-441 $\mathrm{min}$ ) compared with $270 \mathrm{~min}$ (range: 150-373 min) for open surgery ${ }^{(8)}$. However, our operative time was shorter than in any available studies. Although the duration of surgery is not a criterion of comparison, we need to emphasize that the operative time vastly depends on the experience and expertise in laparoscopic surgery.

The introduction of the laparoscopic approach has significantly decreased intraoperative complications as well as postoperative morbidity. We did not encounter any intraoperative or postoperative complications in our patients, similarly to some other studies ${ }^{(10,11,13)}$. The latest study by Vieira et al. found that intraoperative complications such as bladder injury, fallopian tube injury and vascular injury were seen in 3\% of cases in MIS including both laparoscopic and robotic surgeries. Also, they also found that there was not much difference in the rate of postoperative complications in MIS vs. open surgery (30 vs. $31 \%)^{(8)}$ (Tab. 2).

Blood loss during surgery was significantly less in cases of LRT than ART or VRT ${ }^{(1,6-8)}$. In our series of 4 patients, an average intraoperative blood loss was only $80 \mathrm{~mL}$, which was far less than in any other published studies where the blood loss volume was 650,332 , and $185 \mathrm{~mL}^{(11-13)}$. Six out of 27 patients in the study by Kim et al. needed intraoperative blood transfusion ${ }^{(13)}$ (Tab. 2).

Lee et al. in their series of 2 patients noted that the mean postoperative hospital stay was 12.5 days $^{(12)}$, whereas two other studies reported that the mean hospital stay was 9 and 6 days, respectively ${ }^{(11,13)}$. Our 4 patients had an average hospital stay of 4 days (range: 3-6 days). Saadi et al. in their study of 4 patients had a mean length of hospital stay of 33 hours (range: $24-36$ hours) ${ }^{(6)}$. It was the only available study who had a shorter mean hospital stay than ours. Mean number of pelvic lymph node yield was 24 (range: 19-31) in our study. Kim et al. in his 27 patients had 25.7 lymph nodes ${ }^{(13)}$, whereas Lee et al. in their 2 patients observed that the mean number of lymph nodes was as high as $35^{(12)}$. However, one study noted that the median lymph node count was higher in open surgery compared to MIS $(22 \text { vs. } 17)^{(8)}$ (Tab. 2$)$.

Urinary and/or anorectal complaints and sexual dysfunction post radical trachelectomy is closely related to autonomic dysregulations after surgical disruptions ${ }^{(15-18)}$. the preservation of sympathetic nerves in the hypogastric nerve and parasympathetic nerves in the pelvic splanchnic nerve with vesical branches of the pelvic plexus, reduces the chances of autonomic dysfunction ${ }^{(19)}$. Conventional radical trachelectomy (CRT) may increase the days of postoperative catheterization (DPC) and urinary incontinence and frequency ${ }^{(16,17)}$. We removed the Foley catheter on postoperative day 2 in all 4 cases, and none of our patients had any complaints of incontinence, frequency or dysuria. We confirmed bladder function on postoperative day 7 , and at subsequent follow-ups by investigating post-void residual volume which was insignificant in all patients. Kim et al. in their meta-analyses of 2,253 patients from January 2000 to February 2014 concluded that autonomic nerve preservation in nerve-sparing radical trachelectomy (NSRT) had significant impact on urinary function, and observed that DPC was shorter, and urinary incontinence and frequency were less common in NSRT ${ }^{(15)}$.

Barnes et al. mentioned that injury to the pelvic autonomic nerves in CRT might cause internal sphincter dysregulation and decreased rectal sensation ${ }^{(20)}$. We found no anorectal complaints such as constipation, diarrhea or fecal incontinence in our patients until the last follow-up. We observed that in our patients bowel function returned to normalcy on postoperative day 2. A meta-analysis hypothesized that NSRT might reduce the incidence of functional defecation disorders such as constipation, like in our study ${ }^{(15)}$.

One of the major advantages of TLNSRT is preserving sexual function in young females. Currently, there are no relevant studies comparing CRT and TLNSRT in terms of sexual dysfunction outcomes. We in our 4 cases carefully compiled the data on the patients' sexual functionality in the post-surgery period. All our patients were allowed coitus 4 weeks after surgery. In our series, none of the patients had any complaints of vaginal dryness or difficulty in lubrication during the coitus. We found no dyspareunia or inability to achieve an orgasm. Three out of 4 patients rated their post-surgical sexual activity as GOOD, and it was comparable to their sexual function prior to surgery. Available literature data suggests that autonomic nerves damage during CRT may change the neurogenic control of the blood vessels of the vaginal wall, disturbing the vaginal blood flow during sexual arousal and lubrication, and leading to poor sexual activity ${ }^{(21,22)}$. Kim et al. in their large analysis concluded that only autonomic nerve preservation might not be associated with an improvement in sexual functions, and the authors believe that post-surgery vaginal shortness, tissue fibrosis, radiotherapy, ovarian function status, and psychological factors might also be linked to the sexual function outcome $e^{(15)}$.

Preserving fertility is the major goal of LRT. We carefully monitored all our patients during the postoperative followup period, and noticed that 3 out of 4 patients had their regular menstruation in the first postoperative month, and the remaining patient had her menstrual cycle in the second postoperative month. Three out of 4 patients in our series 
attempted to conceive, and 2 succeeded. We did not find any miscarriages post-surgery in our series. In a series of 27 patients studied by Kim et al., a total of 6 patients attempted to conceive, and 3 were able to get pregnant ${ }^{(13)}$. Out of these 3 patients, 2 patients had a miscarriage. Ebisawa et al. in their retrospective study of 56 patients found that 25 women attempted to conceive, and 13 succeeded, for a total of 21 pregnancies $^{(23)}$. Five patients had first trimester miscarriages, 2 patients - second trimester miscarriages, and 13 live births. There are also some case series in which patients could not conceive to date ${ }^{(2,11)}$ (Tab. 2).

A retrospective review of 4 institutions where patients underwent radical trachelectomy for early-stage cervical cancer found that there was only one recurrence in a patient who underwent ART and none in $\mathrm{LRT}^{(8)}$. We did not find recurrence in our 4 patients during 2 years of follow-up, like in some other studies ${ }^{(2,12)}$. Kim et al. in their series of 27 patients found recurrence in only 1 patient ${ }^{(13)}$, similarly to a few other studies ${ }^{(9-11)}$ (Tab. 2).

\section{CONCLUSION}

We found that laparoscopic radical trachelectomy was the best available technique for early-stage cervical cancer in women desirous of children. Nerve-sparing techniques specifically enable the prevention of urinary dysfunction, anorectal problems and sexual problems postoperatively. Laparoscopic radical trachelectomy is minimally invasive in nature, with a shorter recovery time.

We conclude that laparoscopic nerve-sparing radical trachelectomy is a novel approach to minimally invasive gynecologic cancer surgery, and a major breakthrough in the field of reproductive medicine (if performed by trained surgeons), with excellent perioperative outcomes. Further such studies will definitely contribute to building consensus about these findings.

\section{Conflict of interest}

No conflict of interest with respect to any financial or commercial entities. No conflict of interest amongst authors regarding the subject matter in the manuscript or submission.

\section{References}

1. Gizzo S, Ancona E, Saccardi C et al.: Radical trachelectomy: the first step of fertility preservation in young women with cervical cancer (Review). Oncol Rep 2013; 30: 2545-2554.

2. Rendón GJ, Ramirez PT, Frumovitz M et al.: Laparoscopic radical trachelectomy. JSLS 2012; 16: 503-507.
3. Dargent D, Brun JL, Roy M et al.: La trachelectomie elargie (TE), une alternative a l'hysterectomie radical dans le traitment des cancers infiltrants developpes sur la face externe du col uterin. J Obstet Gynecol 1994; 2: 285-292.

4. Smith JL, Boyle DC, Corless DJ et al.: Abdominal radical trachelectomy: a new surgical technique for the conservative management of cervical carcinoma. Br J Obstet Gynaecol 1997; 104: 1196-1200.

5. Rob L, Skapa P, Robova H: Fertility-sparing surgery in patients with cervical cancer. Lancet Oncol 2011; 12: 192-200.

6. Saadi JM, Perrotta M, Orti R et al.: Laparoscopic radical trachelectomy: technique, feasibility, and outcomes. JSLS 2015; 19: e2013.00248.

7. Cibula D, Ungár L, Pálfalvi L et al.: Laparoscopic abdominal radical trachelectomy. Gynecol Oncol 2005; 97: 707-709.

8. Vieira MA, Rendón GJ, Munsell $M$ et al.: Radical trachelectomy in early-stage cervical cancer: a comparison of laparotomy and minimally invasive surgery. Gynecol Oncol 2015; 138: 585-589.

9. Martin A, Torrent A: Laparoscopic nerve-sparing radical trachelectomy: surgical technique and outcome. J Minim Invasive Gynecol 2010; 17: 37-41.

10. Bafghi A, Castaigne D, Pomel C: Radical trachelectomy: from the laparoscopic approach to the vaginal route. J Gynecol Obstet Biol Reprod (Paris) 2006; 35: 696-701.

11. Park NY, Chong GO, Cho YL et al.: Total laparoscopic nerve-sparing radical trachelectomy. J Laparoendosc Adv Surg Tech A 2009; 19: $53-58$.

12. Lee CL, Huang KG, Wang CJ et al.: Laparoscopic radical trachelectomy for stage Ib1 cervical cancer. J Am Assoc Gynecol Laparosc 2003; 10: 111-115.

13. Kim JH, Park JY, Kim DY et al.: Fertility-sparing laparoscopic radical trachelectomy for young women with early stage cervical cancer. BJOG 2010; 117: 340-347.

14. Kucukmetin A, Biliatis I, Ratnavelu N et al.: Laparoscopic radical trachelectomy is an alternative to laparotomy with improved perioperative outcomes in patients with early-stage cervical cancer. Int J Gynecol Cancer 2014; 24: 135-140.

15. Kim HS, Kim K, Ryoo SB et al.: Conventional versus nerve-sparing radical surgery for cervical cancer: a meta-analysis. J Gynecol Oncol 2015; 26: 100-110.

16. Querleu D, Narducci F, Poulard V et al.: Modified radical vaginal hysterectomy with or without laparoscopic nerve-sparing dissection: a comparative study. Gynecol Oncol 2002; 85: 154-158.

17. Todo $\mathrm{Y}$, Kuwabara $\mathrm{M}$, Watari $\mathrm{H}$ et al.: Urodynamic study on postsurgical bladder function in cervical cancer treated with systematic nerve-sparing radical hysterectomy. Int J Gynecol Cancer 2006; 16 : 369-375.

18. Raspagliesi F, Ditto A, Hanozet F et al.: Nerve-sparing radical hysterectomy in cervical cancer: evolution of concepts. Gynecol Oncol 2007; 107 (Suppl 1): S119-S121.

19. Rob L, Halaska M, Robova H: Nerve-sparing and individually tailored surgery for cervical cancer. Lancet Oncol 2010; 11: 292-301.

20. Barnes W, Waggoner S, Delgado G et al.: Manometric characterization of rectal dysfunction following radical hysterectomy. Gynecol Oncol 1991; 42: 116-119.

21. Pieterse QD, Ter Kuile MM, Deruiter MC et al.: Vaginal blood flow after radical hysterectomy with and without nerve sparing. A preliminary report. Int J Gynecol Cancer 2008; 18: 576-583.

22. Maas CP, ter Kuile MM, Laan E et al.: Objective assessment of sexual arousal in women with a history of hysterectomy. BJOG 2004; 111: 456-462.

23. Ebisawa K, Takano M, Fukuda M et al.: Obstetric outcomes of patients undergoing total laparoscopic radical trachelectomy for early stage cervical cancer. Gynecol Oncol 2013; 131: 83-86. 